\title{
CULTIVATION PECULIARITIES OF UNDER THE INFLUENCE OF MICROBIAL PREPARATIONS, FERTILIZATION AND SOIL TILLAGE IN THE NORTHERN STEPPES REGION OF UKRAINE
}

\author{
Grigorieva E. N.
}

Kirovohrad State Agricultural Experimental Station NAAS

2, Tsentralna str., Sozonivka, Kirovograd region, 27602, Ukraine e-mail: grigorjeva_elena@mail.ru

The paper presents the research results of the efficiency study of biological products in corn growing technologies on different fertilization background and main soil tillage practices. The positive effect of microbial preparations on crop yields and output quality was established.

Keywords: microbial drugs, plant growth regulator, fertilization background, tillage, corn.

The solution to the food supply problem and welfare improvement of Ukraine is largely dependent on the development of agriculture and its efficiency increase. The basis for high yields formation, in addition to the genetic potential of the plants is the technology of their cultivation.

Corn - one of the most valuable crops. Its outputs are used in animal husbandry, food and processing industries. In some countries, about $20-35 \%$ of the gross corn harvest is used for food needs, 15-20\% - for technical, and 50-65 $\%$ for livestock feeding $[1,2]$. Growing demand for corn on both domestic and foreign markets necessitates the yield increase of this universal culture.

The research results conducted for several years in different soil-climatic zones of Ukraine and abroad, testify the positive impact of deep main tillage on the growth, development and productivity of corn [3]. Fertilization - is one of the effective technological measures used for improvement of corn productivity. Corn versus other grains responds better to fertilization and due to the long growing season uptakes nutrients from the soil almost till the end of grain ripening [4].

Pre-sowing seeds bacteryzation along with the use of fertilizers in corn growing is one of the promising agricultural means. Use of microbial preparations in agriculture promotes not only increase in plant productivity but also in grain quality, and also creates a high concentration of useful forms of microorganisms in the root zone of plants, which in turn positively affects the passage of specific biological processes in soil [5]. Pre-sowing seeds bacterization sometimes is quite difficult to combine with other agricultural means - like pesticides treatment to protect seeds from pathogens. Nowadays there is an industrial (factory) technology of simultaneous seeds bacteryzation with protectants, which solves this problem [6].

Efficient and rational use of fertilizers, optimization of plants nutrition through the use of modern biological preparations is one of the priority means that can provide a guaranteed and competitive production of corn. Thus, the efficiency 
study of the microbial preparations at cultivation corn at different fertilization and tillage is relevant and is of a practical importance.

Materials and methods. The study of the combined effect of biological preparations at pre-sowing seeds bacteryzation combined with foliar treatment of crops with growth regulator on different backgrounds of mineral fertilizer and basic soil tillage methods on the corn productivity in the Northern Steppe of Ukraine were conducted in field experiments by three factor scheme for the period 2011-2013 (Table 1).

Experiments were conducted using two primary tillage means - plowing to a depth of 25-27 cm and disking on the depth of 12-14 cm. The following fertilizer systems were used: 1 - without fertilizers; $2-\mathrm{N}_{20} \mathrm{P}_{20} \mathrm{~K}_{20} ; 3-\mathrm{N}_{40} \mathrm{P}_{40} \mathrm{~K}_{40}$. In each system there were variants without the use of biological preparations and with seeds inoculation using microbial preparation Agrobacteryn, $60 \mathrm{ml}$ per hectare norm of seeds and Biogran, both separately and in combination with a growth regulator Biolan $(20 \mathrm{ml} / \mathrm{ha})$. Foliar application of growth regulator was performed at phase of 6-8 corn leaves. Corn hybrid used in the experiments Lyubava $279 \mathrm{MV}$.

Pre-crop - soybeans. The growing technology - common for the area, except for the studied factors. Experiments establishment, observation, recording and sampling was carried out in accordance to the methods of field experiment by Dospehov [7].

Seed inoculation was carried out at the same day with planting using conventional methods for bacterial preparations use and manufacturers recommendations [8].

The experiments were performed on plain black heavy clay loam soils. According to the research center "Oblderzhrodyuchyst" the plow layer contains on average $4.69 \%$ of humus, easily hydrolyzed nitrogen -13.7 , mobile phosphorus 10.0 and exchangeable potassium $-15.1 \mathrm{mg} / 100 \mathrm{~g}$ of soil.

Hydrothermal coefficient (HTC) is used to describe corn provision with moisture and heat during certain periods of plant growth and development and for the whole growing season. In 2011 the average HTC figure during vegetative period of corn was 0.75 while the average long-term index is 1.05 . However, it should be noted that in the critical period of growth and development of corn HTC was 2.3 at a norm of 1.18 , which made it possible to obtain a relatively high yields of corn. During the 2012 growing season the HTC was 0.48. In April, it was below the long-term index up to $70.4 \%$. In May - by $65.3 \%$, in June - by $62.7 \%$, in July - by 50.9\%, in August and September - 48.7\% and 81,4\%, respectively. At a critical period of corn growth and development (second-third decade of June) hydrothermal coefficient was within the 0.03 to 0.19 range, which had indicated the significant shortage of rainfall and severe drought. Such weather conditions had affected the final crop productivity. In 2013 the HTC in April was 0.5 at a norm of 1.35. In May and June the HTC values were close to the average indices. July and August were characterized with higher ( 2.8 and $3.3{ }^{\circ} \mathrm{C}$, respectively) average air temperature as compared to the long-term average and lack of effective precipitation. HTC during this period was respectively 0.4 and 0.3 , at long-term 
average -1.16 and 0.80 . Optimal soil moisture level during the critical period of corn development had ensured the formation of high yields.

Results and discussion. Comprehensive analysis of the growing conditions of corn under the use of microbial preparations, both separately and in combination with plant growth regulators, in different ways and on different fertilizer background and different main soil tillage techniques had showed the significant dependence of corn yield from the investigated factors and environmental conditions.

Under the sufficient moisture conditions in 2011 a relatively high corn yield was formed in variants with both tillage means. Thus, plowing either on the background without fertilizers or at application of $20 \mathrm{~kg} / \mathrm{ha}$ of active ingredient had a higher grain yield in the variants with pre-sowing seeds inoculation with phosphorous mobilizing preparation Agrobacteryn - 11.99 and $12.12 \mathrm{t} / \mathrm{ha}$ that is respectively 1.42 and $1.55 \mathrm{t} / \mathrm{ha}$ or 13.4 and $14.7 \%$ increment over the control (without fertilizers and without inoculation). In variants with the highest fertilizers background the highest values were obtained in variants with seeds bacteryzation with microbial preparation of complex action Biogran followed by foliar application with Biolan. That which gave extra $2.22 \mathrm{t} / \mathrm{ha}$ or $21.0 \%$, compared to the absolute control and $1.27 \mathrm{t} / \mathrm{ha}$ or $11.0 \%$ - to the variant without seed treatment in same experimental block (Table 1).

At minimal tillage technology (disking to a depth of $12-14 \mathrm{~cm}$ ) at natural background and at application of $\mathrm{N}_{20} \mathrm{P}_{20} \mathrm{~K}_{20}$ the Biogran preparation was shown to be most efficient. That allows to receive respectively, 1.02 and $2.25 \mathrm{t} / \mathrm{ha}$ compared to the absolute control. Both at plowing and disking on the $\mathrm{N}_{40} \mathrm{P}_{40} \mathrm{~K}_{40}$ background the highest yields were obtained in the variant with combined application of Biogran with Biolan - $10.47 \mathrm{t} / \mathrm{ha}$ at $8.17 \mathrm{t} / \mathrm{ha}$ level in absolute control.

In dry conditions in 2012 for plowing at all studied fertilizers backgrounds, the significantly high increase of corn yield comparing to the absolute control (without fertilizer and without seed treatment) was formed in variants with seeds bacteryzation with microbial preparation Biogran $-0.55 \mathrm{t} / \mathrm{ha}(14.2 \%)-$ on natural background; $0.81 \mathrm{t} / \mathrm{ha}(21.0 \%)$ - at $20 \mathrm{~kg} / \mathrm{ha}$ of fertilizer; $0.52 \mathrm{t} / \mathrm{ha}(13.5 \%)$ - at $\mathrm{N}_{40} \mathrm{P}_{40} \mathrm{~K}_{40}$ background.

The maximum yield under disking on the background without fertilizers and application of $\mathrm{N}_{20} \mathrm{P}_{20} \mathrm{~K}_{20}$ was received in variants with seeds treatment with Biogran -3.45 and $3.58 \mathrm{t} / \mathrm{ha}$, respectively, which gave the opportunity to get extra 0.55 and $0.68 \mathrm{t} / \mathrm{ha}$ of grain compared to the control. Pre-sowing seeds bacteryzation with microbial preparation Agrobacteryn wasshown to be the most efficient on the highest fertilizers background $-\mathrm{N}_{40} \mathrm{P}_{40} \mathrm{~K}_{40}$.

In the agro-climatic conditions for that year in variants with complex use of microbial preparations for seed treatment and foliar treatment of crops during the growing season with growth regulator Biolan the yield shortfall was observed - on both tillage systems and fertilizer backgrounds, compared to plots with pre-sowing seeds inoculation. On average, this index within the experiment had ranged $0.01-$ $0.86 \mathrm{t} / \mathrm{ha}$. 
Table 1. Influence of biological preparations, fertilization and tillage systems on corn yield

\begin{tabular}{|c|c|c|c|c|c|c|c|c|}
\hline \multirow{2}{*}{ 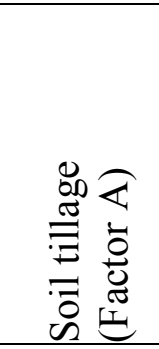 } & \multirow{2}{*}{ 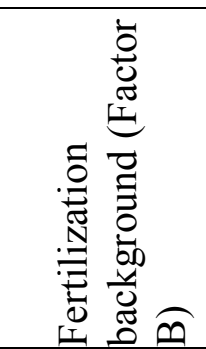 } & \multirow[t]{2}{*}{$\begin{array}{l}\text { Biological } \\
\text { preparations } \\
\text { (Factor C) }\end{array}$} & \multicolumn{4}{|c|}{ Years of study } & \multicolumn{2}{|c|}{$\begin{array}{l}\text { Increment to } \\
\text { control (w/o } \\
\text { fertilizers and } \\
\text { w/o seed } \\
\text { treatment) }\end{array}$} \\
\hline & & & 2011 & 2012 & 2013 & $\begin{array}{l}\text { Avera } \\
\text { ge }\end{array}$ & $\mathrm{t} / \mathrm{ha}$ & $\%$ \\
\hline \multirow{19}{*}{ Plowing } & \multirow{5}{*}{$\begin{array}{l}\text { W/o } \\
\text { fertilizers } \\
\text { (control) }\end{array}$} & No treatment & 10,57 & 3,86 & 7,53 & 7,32 & - & - \\
\hline & & Agrobacteryn & 11,99 & 4,38 & 7,96 & 8,11 & 0,79 & 10,8 \\
\hline & & $\begin{array}{l}\text { Agrobacteryn + } \\
\text { Biolan }\end{array}$ & 11,57 & 4,38 & 8,42 & 8,12 & 0,80 & 10,9 \\
\hline & & Biogran & 11,95 & 4,41 & 8,41 & 8,26 & 0,94 & 12,8 \\
\hline & & Biogran + Biolan & 10,96 & 4,16 & 7,97 & 7,70 & 0,38 & 5,2 \\
\hline & $\begin{array}{l}\text { Average for } \\
\text { backgrounc }\end{array}$ & ertilizers & 11,41 & 4,24 & 8,06 & 7,90 & $x$ & $x$ \\
\hline & & No treatment & 11,35 & 3,87 & 8,03 & 7,75 & 0,43 & 5,9 \\
\hline & & Agrobacteryn & 12,12 & 4,51 & 8,33 & 8,32 & 1,00 & 13,7 \\
\hline & $\mathrm{N}_{20} \mathrm{P}_{20} \mathrm{~K}_{20}$ & $\begin{array}{l}\text { Agrobacteryn + } \\
\text { Biolan }\end{array}$ & 12,05 & 4,50 & 8,43 & 8,33 & 1,01 & 13,8 \\
\hline & & Biogran & 11,39 & 4,67 & 8,45 & 8,17 & 0,85 & 11,6 \\
\hline & & Biogran + Biolan & 12,00 & 4,27 & 8,31 & 8,19 & 0,87 & 11,9 \\
\hline & $\begin{array}{l}\text { Average for } \\
\text { backgrounc }\end{array}$ & ertilizers & 11,78 & 4,36 & 8,31 & 8,15 & $x$ & $x$ \\
\hline & & No treatment & 11,52 & 4,14 & 7,53 & 7,73 & 0,41 & 5,6 \\
\hline & & Agrobacteryn & 12,34 & 4,28 & 7,81 & 8,14 & 0,82 & 11,2 \\
\hline & $\mathrm{N}_{40} \mathrm{P}_{40} \mathrm{~K}_{40}$ & $\begin{array}{l}\text { Agrobacteryn + } \\
\text { Biolan }\end{array}$ & 11,64 & 4,05 & 7,69 & 7,79 & 0,47 & 6,4 \\
\hline & & Biogran & 11,82 & 4,38 & 7,98 & 8,06 & 0,74 & 10,1 \\
\hline & & Biogran + Biolan & 12,79 & 4,15 & 8,07 & 8,34 & 1,02 & 13,9 \\
\hline & $\begin{array}{l}\text { Average for } \\
\text { backgrounc }\end{array}$ & rtilizers & 12,02 & 4,20 & 7,82 & 8,01 & $x$ & $x$ \\
\hline & Average for & oil tillage & 11,74 & 4,27 & 8,06 & 8,02 & $\mathrm{x}$ & $x$ \\
\hline \multirow{13}{*}{ Disking } & & No treatment & 8,17 & 2,90 & 7,17 & 6,08 & - & - \\
\hline & & Agrobacteryn & 9,07 & 3,36 & 7,67 & 6,70 & 0,62 & 10,2 \\
\hline & fertilizers & $\begin{array}{l}\text { Agrobacteryn + } \\
\text { Biolan }\end{array}$ & 8,92 & 3,33 & 7,70 & 6,65 & 0,57 & 9,4 \\
\hline & & Biogran & 9,19 & 3,45 & 7,61 & 6,75 & 0,67 & 11,0 \\
\hline & & Biogran + Biolan & 8,96 & 3,32 & 7,78 & 6,69 & 0,61 & 10,0 \\
\hline & $\begin{array}{l}\text { Average for } \\
\text { backgrounc }\end{array}$ & rtilizers & 8,86 & 3,27 & 7,59 & 6,57 & $x$ & $x$ \\
\hline & & No treatment & 8,34 & 2,96 & 7,37 & 6,22 & 0,14 & 2,3 \\
\hline & & Agrobacteryn & 9,21 & 3,24 & 7,65 & 6,70 & 0,62 & 10,2 \\
\hline & $\mathrm{N}_{20} \mathrm{P}_{20} \mathrm{~K}_{20}$ & $\begin{array}{l}\text { Agrobacteryn + } \\
\text { Biolan }\end{array}$ & 8,53 & 3,54 & 7,66 & 6,58 & 0,50 & 8,2 \\
\hline & & Biogran & 10,42 & 3,58 & 7,80 & 7,27 & 1,19 & 19,6 \\
\hline & & Biogran + Biolan & 8,66 & 3,36 & 7,61 & 6,54 & 0,46 & 7,6 \\
\hline & $\begin{array}{l}\text { Average for } \\
\text { backgrounc }\end{array}$ & ertilizers & 9,03 & 3,34 & 7,62 & 6,66 & $x$ & $x$ \\
\hline & $\mathrm{N}_{40} \mathrm{P}_{40} \mathrm{~K}_{40}$ & No treatment & 9,73 & 3,05 & 7,59 & 6,79 & 0,71 & 11,7 \\
\hline
\end{tabular}




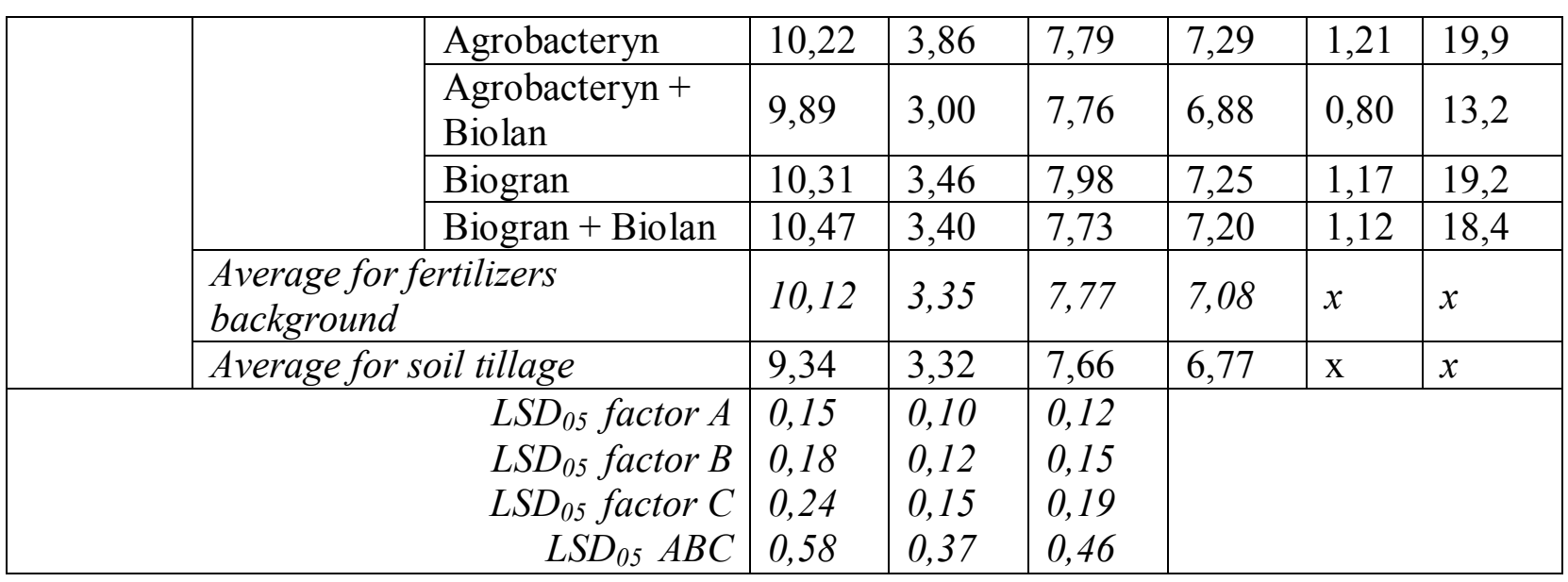

In 2013 at plowing to a depth of $25-27 \mathrm{~cm}$ the significantly higher corn yield was formed in variants with seeds treatment with microbial preparation of complex action Biogran on all fertilizers backgrounds. Thus, on the background without fertilizers and application of $\mathrm{N}_{20} \mathrm{P}_{20} \mathrm{~K}_{20}$ at seed inoculation it was, respectively, 8.41 and 8.45 t/ha. For $\mathrm{N}_{40} \mathrm{P}_{40} \mathrm{~K}_{40}$, in combination with foliar treatment of crops with growth regulator Biolan the yield was $8,07 \mathrm{t} / \mathrm{ha}$. This gave the opportunity to receive an extra $0.86 ; 0.92$ and $0.54 \mathrm{t} / \mathrm{ha}$ or $11.8 ; 12.2$ and $7.2 \%$ of grain respectively, compared to the control without fertilizer and without seed treatment.

In variants with disking higher yields were obtained under the use of microbial preparation of complex action Biohran. On the background without fertilizers the maximum yield of corn grain was formed in variants with seeds inoculation and foliar treatment with Biolan $-7.78 \mathrm{t} / \mathrm{ha}$, which was $0.61 \mathrm{t} / \mathrm{ha}$ higher compared to the control without inoculation. Use of Biogran at $\mathrm{N}_{20} \mathrm{P}_{20} \mathrm{~K}_{20}$ and $\mathrm{N}_{40} \mathrm{P}_{40} \mathrm{~K}_{40}$ fertilizers backgrounds for pre-sowing seeds treatment had ensured receipt of additional yield compared to the control without fertilization and inoculation $-0.63 \mathrm{t} / \mathrm{ha}(8.5 \%)$ and $0.81 \mathrm{t} / \mathrm{ha}(11.3 \%)$, respectively.

The research data have shown that the average corn yield increase for 20112013 ensured by the use of biological preparations was $0.47-0.58 \mathrm{t} / \mathrm{ha}(6.2-$ $7.6 \%) \mathrm{n}$ variants with plowing and $0.38-0.73 \mathrm{t} / \mathrm{ha}(6.0-11.5 \%)-$ in variants with disking. The average data over the experiment had indicated that deeper tillage (plowing to a depth of 25-27 cm) compared to the shallow $(12-14 \mathrm{~cm}$ disking) had ensured corn yield increase from 6.77 to 8.02 t/ha. Application of fertilizers in variants with plowing had provided the yield increase of $7.90 \mathrm{t} / \mathrm{ha}$ in the plots where studies were conducted on a natural background and $8.15 \mathrm{t} / \mathrm{ha}$ on a $\mathrm{N}_{20} \mathrm{P}_{20} \mathrm{~K}_{20}$ background. Higher mineral fertilizers doses $(40 \mathrm{~kg} / \mathrm{ha}$ of active ingredient) had resulted in yield decrease $-8.01 \mathrm{t} / \mathrm{ha}$. For variants with shallow tillage corn yield under the different fertilizing systems had increased from 6.57 $\mathrm{t} / \mathrm{ha}$ on a natural background, respectively, to 6.66 and $7.08 \mathrm{t} / \mathrm{ha}$ at application of mineral fertilizers at doses 20 and $40 \mathrm{~kg} / \mathrm{ha}$ of active ingredient.

It should be noted that biological preparations had the maximum impact on the formation of biological productivity of corn in experiment conducted in 2012 characterized with the drought conditions. Corn yield through the use of biological 
preparations in 2012 had increased from 9.0 to $15.6 \%$. In 2011 these figures was $4.8-9.0 \%$, in $2013-4.4-6.6 \%$.

The results of starch content in corn had indicated the higher values for this figure in variants with plowing on natural background under the seeds treatment with Agrobacteryn - 66.93\%, which was $2.34 \%$ higher comparing to control without inoculation. In other variants yield the decrease of this quality indicator on $0.04-4.52 \%$ was observed (Fig. 1).

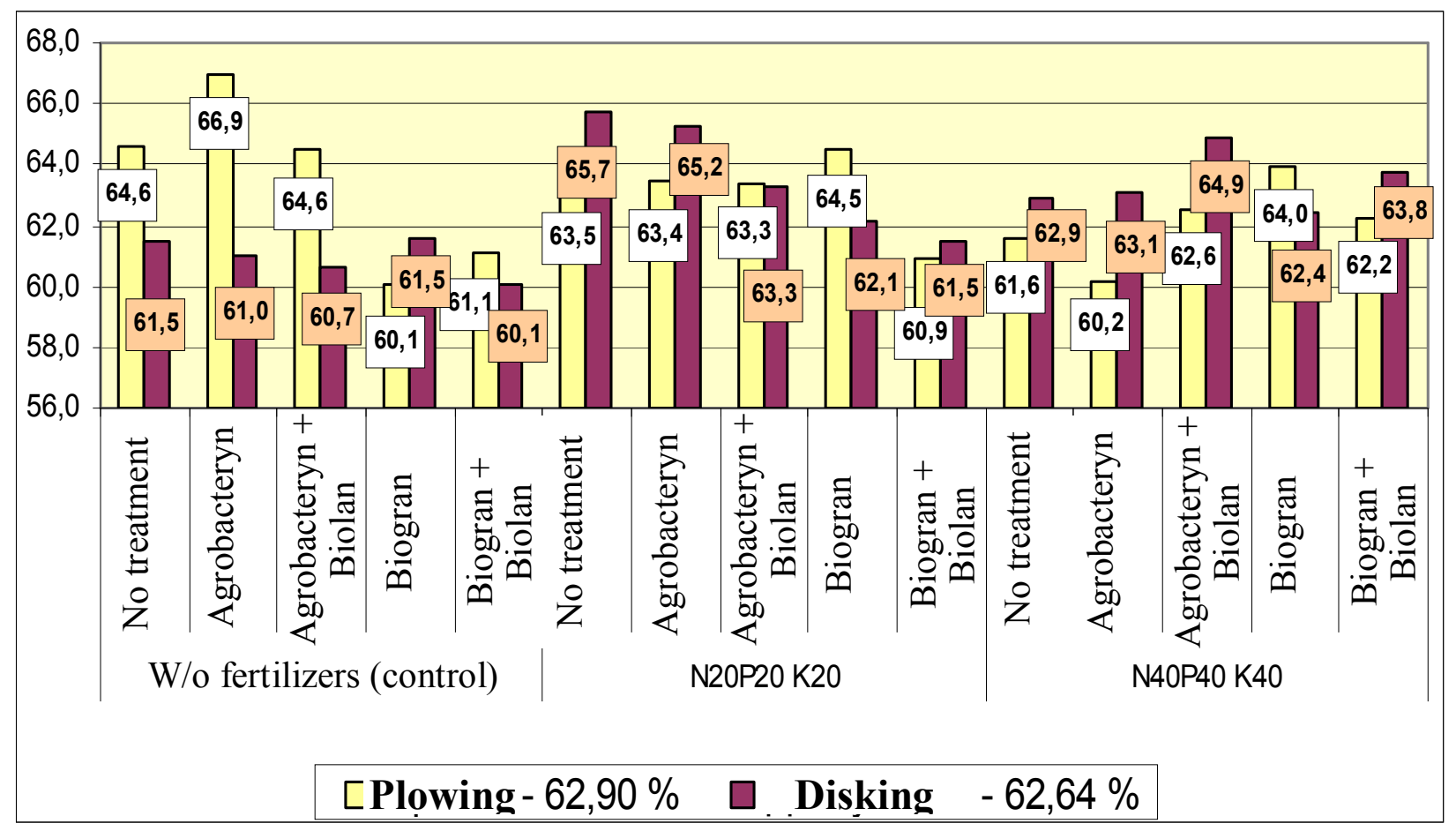

Fig. 1. Influence of studied factors on the starch content in corn seed, average for 2011-2013, \%

Application of mineral fertilizers with main tillage in doses $\mathrm{N}_{20} \mathrm{P}_{20} \mathrm{~K}_{20}$ and $\mathrm{N}_{40} \mathrm{P}_{40} \mathrm{~K}_{40}$ in control variant (without inoculation) the gradual decrease in starch content in seeds was observed -1.10 and $2.98 \%$, respectively. However, the use of biological products in the blocks with mineral fertilizers the starch content as compared to the control values had increased. Using 20 and $40 \mathrm{~kg} / \mathrm{ha}$ of active ingredient the highest values in the variant with Biogran. The starch content was higher compared to control, respectively, by 1.00 and $2.35 \%$. Application of biological products had not contributed to the increase of starch content in corn at corn growing at shallow soil tillage.

Estimation of economic efficiency of corn growing confirm the general pattern: the use of microbial preparations was more effective on the background without fertilizers, while at higher fertilizer doses the profitability level had decreased. Due to the yield differences depending on the studied technological means and variability of production costs the profitability had also changed. The best values of relatively net profit and higher profitability indicators were obtained in variants with plowing. Disking had resulted in lower values of studied these indices. Thus, relatively net profit form the use of biological preparations on 
various fertilizers background under the deep tillage had ranged from 5137 to $7120 \mathrm{USD} /$ ha at profitability level $109.8-196.8 \%$, hallow tillage had respectively, 4 261-5 $560 \mathrm{UAH} / \mathrm{ha}$ and $91.0-172.9 \%$.

The use of microbial preparations was shown to be a promising agricultural practice and efficiency reserve for corn growing in arid regions of Northern Steppe Ukraine. It ensures high grain yields at favorable weather conditions at deep tillage (plowing to a depth of 25-27 cm), and shallow tillage (disking on depth of 12-14 $\mathrm{cm})$. At crops growing on natural background at both studied tillage methods for better effect it is recommended to use pre-sowing seeds inoculation with microbial preparation of complex action Biogran, that in average for 2011-2013 had ensured extra $0.94 \mathrm{t} / \mathrm{ha}(12.8 \%)$ of grain in plots with plowing and $0.67 \mathrm{t} / \mathrm{ha}(11.0 \%)$ - in plots with disking. At corn growing using moderate doses of mineral fertilizers (20 $\mathrm{kg} / \mathrm{ha}$ active ingredient) using plowing it is recommended to use Agrobacteryn for seeds bacterization, while at disking it is recommended to use Biogran. Both preparations ensure yield increase by 13.7 and $19.6 \%$, respectively. 